\title{
CALDERON COKEMAKING \\ PROCESS/DEMONSTRATION PROJECT
}

Quarterly Technical Report

Reporting Period: Start Date: 02/26/1998 End Date: 05/25/1998

Author: ALBERT CALDERON

Report Issue Date:06/22/1998

DE-FC22-95PC92638--12

CALDERON ENERGY COMPANY

500 Lehman Avenue

P.O. Box 126

Bowling Green, OH 43402 


\section{DISCLAIMER}

This report was prepared as an account of work sponsored by an agency of the United States Government. Neither the United States Government nor any agency thereof, nor any of their employees, makes any warranty, express or implied, or assumes any legal liability or responsibility for the accuracy, completeness, or usefulness of any information, apparatus, product, or process disclosed, or represents that its use would not infringe privately owned rights. Reference herein to any specific commercial product, process, or service by trade name, trademark, manufacturer, or otherwise does not necessarily constitute or imply its endorsement, recommendation, or favoring by the United States Government or any agency thereof. The views and opinions of authors expressed herein do not necessarily state or reflect those of the United States Government or any agency thereof. 


\section{FINAL QUARTERLY TECHNICAL PROGRESS REPORT \\ CALDERON COKEMAKING PROCESS/DEMONSTRATION PROJECT \\ CALDERON ENERGY COMPANY \\ COOPERATIVE AGREEMENT NO. DE-FC22-95PC92638}

Reporting Period: 2-26-98 to 5-25-98

Date of Report: 6-19-98; Award Date: 5-25-95; Anticipated Completion Date: 11-25-98

Total Project: $\$ 7,354,195.00 \quad$ Total DOE Share: $\$ 3,039,389.00$

Contracting Officer's Representative (COR): Dr. Michael J. Baird;

Project Director: Albert Calderon

$\underline{\text { Abstract }}$

This project deals with the demonstration of a coking process using proprietary technology of Calderon, with the following objectives geared to facilitating commercialization:

(i) making coke of such quality as to be suitable for use in hard-driving, large blast furnaces;

(ii) providing proof that such process is continuous and environmentally closed to prevent emissions;

(iii) demonstrating that high-coking-pressure (non-traditional) coal blends which cannot be safely charged into conventional by-product coke ovens can be used in the Calderon process; and

(iv) demonstrating that coke can be produced economically, at a level competitive with coke imports.

The activities of the past quarter were focused on three main activities:

- Continuation of design of the coking reactor;

- $\quad$ Raising funds from the private sector; and

- Detailed analysis of the tests conducted in Alliance, Ohio. 
The design of the reactor work centered on the provision for the capability to inspect and maintain the internals of the reactor. The activities relating to raising funds from the steel industry have been fruitful. Bethlehem Steel has agreed to contribute funds. The collected data from the tests at Alliance were analyzed and a detailed report was completed and presented to the International Iron \& Steel Institute by invitation. 


\section{TABLE OF CONTENTS}

Introduction

Page 1

Accomplishments and Discussion

Page 1

Conclusion

Page 12 


\section{Introduction}

The commercialization path of the Calderon cokemaking process consists of the following general phases:

Phase I-- Proof of capability to produce acceptable product coke, proof of the process being environmentally closed, proof that non-conventional coal blends can be used, and proof that coke can be economically produced domestically using U.S. metallurgical coals at a level competitive with low cost-producer coke produced from foreign countries that are not subjected to U.S. environmental standards.

Phase II-- Scale-up of coking reactor to full commercial size (PDU-II) in support of first commercial facility.

Phase III-- Construction and operation of first commercial facility.

Phase IV-- Worldwide commercialization of the technology to produce coke competitive with that produced by low-cost producer coke-exporting countries.

\section{Accomplishments and Discussion}

During the past quarter the work was focused on the following activities:- (1) continuation of the design of the coking reactor; (2) raising funds from the steel industry; and (3) detailed analysis of the data collected during the tests conducted in Alliance, Ohio, and the issue of a report for the presentation to the International Iron and Steel Institute by Bethlehem Steel and U.S. Steel on April 28, 1998.

The design of the reactor centered on the following provisions:

- The capability to have access to maintain the reactor. 
- The mounting of the heating elements within the reactor to allow for expansion and contraction.

- A weight up-date of the reactor.

- A transfer jack-car mounted on rails for supporting the coal charging mechanism while the internals of the reactor are inserted or extracted.

The activities relating to raising funds from the steel industry have been fruitful. Bethlehem Steel has agreed to contribute $\$ 3.3$ million. U.S. Steel has the matter under consideration.

Since the completion of the test work at Alliance, Ohio, the data collected was jointly analyzed by Bethlehem Steel, U.S. Steel and Calderon. The details of such analysis is reported in the following report which was presented by Bethlehem Steel and U.S. Steel to the International Iron \& Steel Institute on April 28, 1998. The report is reproduced as follows: 


\title{
Evaluation of Metallurgical Coal Blends in the Calderon Coking Reactor
}

\author{
Alan D. Strauss \\ Senior Research Engineer \\ Bethlehem Steel Research \\ Bethlehem, PA 18016 \\ and \\ Joseph S. Giunta \\ Retired \\ U.S. Steel Research Group
}

Paper to be presented at the IISI TECHCO-30 Meeting, in Washington, DC on April 28, 1998, under authorization of Albert Calderon, Calderon Energy Company, P.O. Box 126, Bowling Green, Ohio 43402. 


\section{Evaluation of Metallurgical Coal Blends in the Calderon Coking Reactor}

\section{Introduction}

A new cokemaking process based on continuous coking of coal in a heated tube has been under development by Calderon Energy Company. The process has evolved from pilot plant work conducted at Calderon's Alliance, Ohio process development unit (PDU) in the early 1990's.

The original cokemaking process was based on the continuous feeding and coking of metallurgical coal in a metallic tube. However, the mechanical and metallurgical properties of metallic tubes at high temperatures were considered by many to be unacceptable in this application. To reduce the effects of mechanical and chemical wear on the alloy tube, Calderon converted the continuous process to a two-step process, (1) carbonization at lower temperatures, and (2) final calcining of the coke in a separate vessel. Low temperature coking tests conducted at the LTV Technology Center confirmed that high quality coke could be produced using the two-step method. However, the number of low temperature reactors required to achieve typical plant production capacities and the cost of alloy tubes made the process economically unattractive.

Calderon then returned to the original process but redesigned the reactor tube with refractory heating tiles in place of the metal alloy tube and changed the cross-section of the reactor tube from a small circular shape to a large annular shape. Preliminary results of heat transfer modeling indicate that when using a dry coal feed, an operating temperature of $2300^{\circ} \mathrm{F}$ will reduce the estimated coking time to approximately nine hours. Using these design criteria each reactor tube has an estimated production rate of 8.5 tons of coke per hour and represents a reasonable basis for a commercial cokemaking operation. Considering a 1.0 million ton-per-year coke plant, only 16 reactor tubes of the new design are required as compared with 256 reactor tubes of the original design.

In May of 1997 Albert Calderon asked both U.S. Steel and Bethlehem Steel to support continued work regarding the Calderon Coking Process. Both were interested in the new design but questioned whether quality coke could be made in a process where the coal/coke mass, and the plastic zone, were moving in a tube. To answer this question, a carbonization test program was developed and a series of tests were planned for Calderon Energy's Process Demonstration Unit (PDU) in Alliance, Ohio. Personnel from Calderon Energy Company, U.S. Steel, and Bethlehem Steel conducted the test program during September and October of 1997. The results of that pilot scale test program will be reviewed in this presentation.

\section{Modifications to the Existing Pilot Plant}

The Process Demonstration Unit (PDU) in Alliance, Ohio was designed and constructed under a Cooperative Agreement with the United States Department of Energy (DOE) in 1991. It was designed primarily for steam coal pyrolysis, char gasification, and hot gas cleanup.

The PDU was shut down in 1993 and had been exposed to the weather since that time. Prior to the start of the test program, hydraulic and electrical systems as well as control instrumentation and computer hardware were reconditioned and calibrated. In addition, modifications to the high-pressure vessels were made in order to produce and handle metallurgical coke. Prior to running the carbonization tests in the pilot plant, thermocouples were installed on 
the coal reactor tube in order to determine the temperature gradients along the length of the tube. A high temperature, high-pressure window was installed on the discharge elbow of the reactor to view the discharge end of the tube.

Since the test procedure required that the closed systems be opened to remove the coke, additional gas sampling ports and a nitrogen purge system were installed. Combustible gases were purged from the coke containment vessels and a gas check was completed prior to opening the system and removing the cooled coke.

Finally, to handle the coke, a coke quenching system was designed and installed, the pressure vessels were modified to accommodate coke storage and coke discharge, and a chute arrangement was installed to drop the coke to ground level for sampling and testing.

\section{Pilot Plant Description}

The flowsheet of the modified Process Demonstration Unit (PDU) is shown in Figure 1. Air-dried coal is batch weighed and fed into the system with a cable operated skip hoist. Coal is discharged into a coal surge hopper and flows into a coal lock hopper where it is stored for use. A rotary feed valve discharges a metered amount of coal into the charging tube assembly. At the start of the charge/push cycle, a hydraulically operated pusher ram compresses the loose coal to a high bulk density and pushes it into the heated section of the reactor tube. As the coal charge is pushed into the reactor tube, the entire coal/coke mass within the tube is moved and, at the end of the pusher stroke, an equal volume of coke is displaced from the coke discharge end of the reactor tube.

The reactor is a metal alloy tube approximately 26 feet long. The reactor tube is heated by flue gas from a natural gas fired external combustion chamber. Flue gas exiting the burner travels through a hairpin expansion joint before entering the flue located on the outside of the metal alloy tube. The flue gas exits the flue at the pusher end of the reactor tube and is vented to the atmosphere through a backpressure control valve.

One of the limitations of this system was that it was originally designed for the lower temperature pyrolysis of steam coal, not high temperature carbonization of metallurgical coals. Even when the burner was operated at its maximum heat output and the carbonization heat load was minimized by using a 24-minute cycle time, the coke discharge end of the tube reached a maximum operating temperature that fell short of conventional oven wall temperatures.

One of the benefits of the original system, however, was the high-pressure vessel design, which allowed the carbonization tests to be conducted at high system pressures. During the test program, the system pressure was maintained at approximately 30 psig and the raw coke oven gas was vented through a pressure control valve into a flare stack.

At the discharge end of the reactor tube, the hot coke falls through a quench water spray system and into the coke storage vessel. After approximately two days of continuous operation, the discharge elbow and coke storage vessel are purged with nitrogen to displace the combustible gases. When the system is safe, the blind flange is removed to discharge the coke through a drop chute to the ground where it is weighed and sampled.

\section{Objectives of the Test Program}

The objectives of the test program were to determine the following: 
- First, can high quality blast furnace coke be made in the Calderon Coking Reactor? What are the limits on the quality of coals that can be used to produce high quality coke?

- Second, can conventional coking coal blends be continuously pushed through the tubular reactor? Do higher coking pressures present a problem in pushing the coal/coke mass through the tube?

\section{Selection of Coal Blends for the Test Program}

Four different metallurgical coal blends, which are itemized in the following table, were selected for testing:

Table No. 1

\section{Selection of Coal Blends for the Test Program}

\begin{tabular}{|c|c|c|c|c|}
\hline $\begin{array}{c}\text { Blend } \\
\text { Component }\end{array}$ & $\begin{array}{c}\text { Bethlehem } \\
\text { Steel } \\
\text { Burns Harbor } \\
\text { Blend }\end{array}$ & $\begin{array}{c}\text { U. S. Steel } \\
\text { Gary Blue } \\
\text { Tag Blend }\end{array}$ & $\begin{array}{c}\text { U. S. Steel } \\
\text { Special Low } \\
\text { Volatile } \\
\text { Blend }\end{array}$ & $\begin{array}{c}\text { U. S. Steel } \\
\text { Gary White } \\
\text { Tag Blend }\end{array}$ \\
\hline $\begin{array}{c}\text { High Volatile } \\
\text { Coal }\end{array}$ & $35.0 \%$ & $72.0 \%$ & $25.0 \%$ & $62.0 \%$ \\
\hline $\begin{array}{c}\text { Medium } \\
\text { Volatile Coal }\end{array}$ & $40.0 \%$ & $14.0 \%$ & $25.0 \%$ & $19.0 \%$ \\
\hline $\begin{array}{c}\text { Low Volatile } \\
\text { Coal }\end{array}$ & $25.0 \%$ & $9.5 \%$ & $50.0 \%$ & $12.9 \%$ \\
\hline $\begin{array}{c}\text { Petroleum } \\
\text { Coke }\end{array}$ & $4.5 \%$ & & $6.1 \%$ \\
\hline
\end{tabular}

Bethlehem Steel's Burns Harbor coal blend was selected because it is a premier quality blend designed for wet charge applications and yields typical plant ASTM stability values of approximately $62 \%$ plus one inch. The test program was started with this coal blend because it had the highest probability of success in making quality coke.

The U.S. Steel Gary Blue Tag coal blend is a lower quality, lower cost blend designed for preheated coal charging and also yields typical ASTM stability values of approximately $62 \%$. This blend was selected to help establish the capability of the Calderon process in making high quality coke with lower quality coal blends.

The U.S. Steel Special Low Volatile coal blend was a radical departure from a typical coke plant coal blend because it contained $50 \%$ low volatile coal and was selected to test the limits of the reactor tube when coking high-pressure blends. This coal blend would never be used in conventional slot-oven batteries because of the high wall pressures produced by the high concentration of low volatile coal. This coal blend was selected to determine the capability of the 
Calderon process to continuously push coke when using high pressure producing low volatile coal blends.

The last blend selected was U.S. Steel's Gary White Tag coal blend. This is a high quality blend designed for wet coal charging and yields typical ASTM stability values of 60\%, This blend is slightly lower in quality than the Burns Harbor coal blend and was tested to evaluate the process capability when using a lower concentration of low volatile coal in the blend.

\section{Calderon Coke Quality Results}

The pilot scale carbonization test program was conducted at the modified PDU in September and October of 1997. During this two-month trial, each of the coal blends listed in the previous table were tested and a total of over 32 tons of coke were produced. Cycle times of 12, 24, and 30-minutes were tested and, because of interruptions in the normal cycle times, there was an opportunity to evaluate cokes with various "soak times". The 24-minute cycle time was established as the "standard" operating rate for the carbonization test program.

The Calderon coke quality results, itemized in the following table, include only those cokes that were produced continuously using the 24-minute cycle time and no soak time.

Table No. 2

\section{Calderon Coke Quality Results}

\begin{tabular}{|c|c|c|c|c|c|}
\hline $\begin{array}{c}\text { Coke } \\
\text { Parameter }\end{array}$ & $\begin{array}{c}\text { Benchmark } \\
\text { BF Coke } \\
\text { Value }\end{array}$ & $\begin{array}{c}\text { Bethlehem } \\
\text { Steel Corp. } \\
\text { Burns } \\
\text { Harbor }\end{array}$ & $\begin{array}{c}\text { U. S. Steel } \\
\text { Blue Tag }\end{array}$ & $\begin{array}{c}\text { U. S. Steel } \\
50 \% \text { Low } \\
\text { Volatile }\end{array}$ & $\begin{array}{c}\text { U. S. Steel } \\
\text { White Tag }\end{array}$ \\
\hline V.M. & $<1.00$ & 0.58 & 0.55 & 0.48 & 0.70 \\
\hline Stability & $>60.0$ & 60.0 & 59.6 & 58.5 & 56.5 \\
\hline Size +2" & $>50.0$ & 71.0 & 56.0 & 64.0 & 55.0 \\
\hline Reactivity & $<12.0$ & 11.0 & 13.0 & 12.0 & 11.0 \\
\hline $\begin{array}{c}\text { Bulk } \\
\text { Density }\end{array}$ & $26-30$ & 26 & 27 & 26 & 29 \\
\hline
\end{tabular}

Once the coke was weighed, representative samples were sent to the UEC Laboratory in Monroeville, PA for chemical, physical, and microscopic evaluations. Only volatile matter (V.M., wt. \%), ASTM stability ( $\%+1$ in.), coke size $(\%+2$ in.), Bethlehem Reactivity (\% weight loss), and coke bulk density $\left(\mathrm{lb} / \mathrm{ft}^{3}\right)$ are reported here. The benchmark coke parameters shown in the table are typical values that blast furnace operators would expect from high quality blast furnace coke.

All of the coal blends tested in the Calderon Coking Reactor produced coke with less than $1.0 \%$ volatile matter. This indicates that, for this particular coking time and heat input, the entire coal mass was completely carbonized at the exit end of the reactor tube and no "green coke" was produced. 
All of the coal blends tested produced a quality coke product that looked very similar to by-product oven coke in size, shape, and texture and had stability values ranging from 56.5 to 60.0. The only visible difference was the occurrence of "circular surface rings" which appear to have been caused by the movement of the reacting coal/coke mass through the reactor tube. It was initially thought these rings would provide a fracture plane that would significantly reduce the stability values but this was not the case. The quality of coke that was produced in the Calderon coking reactor during the short duration test program was impressive.

All of the coal blends tested produced coke that was greater than $50 \%+2$ inches in size. This is what would be expected since the 24-minute cycle time with a coal charge of approximately 60 pounds translates to a residence time in the reactor tube of approximately 24 hours. Faster cycle times (12 minute cycle time) were also tried but the reactor had insufficient heat input capability to carbonize the entire coal mass a the exit end of the reactor tube. Since cycle time ultimately affects the production capability and capital cost of the commercial scale plant, additional test work in a full-size reactor tube is required to evaluate the effects of coking rate on coke size and coke quality.

The Bethlehem reactivity indices for all of the cokes tested were excellent. Past studies using conventional cokemaking techniques have shown that reactivity (weight loss after reaction $\mathrm{CO}_{2}$ at $1825^{\circ} \mathrm{F}$ for 2 hours) is dependent primarily on two parameters, coal blend composition and final coking temperature. It was surprising to obtain consistent reactivity values with the range of coal blend compositions used and the relatively low final coking temperatures.

Finally, in terms of coke bulk density, all of the cokes tested had values in the range of 26 to $29 \mathrm{lb} / \mathrm{ft}^{3}$. The bulk densities of the coke obtained were normal and this coke should perform as well as slot-oven coke in the blast furnace.

Overall, it was found that the Calderon coking process produced good quality metallurgical coke from each of the coal blends tested and there were no apparent problems with pushing the coal/coke mass through the reactor tube. The simplicity of operation was impressive, as was the ease with which the pilot plant was brought on-line after a 5-year shutdown.

\section{Potential Advantages of the Calderon Process}

The pilot plant testing of the Calderon Cokemaking Process revealed the following potential advantages which have been grouped into three major areas, 1) process, 2) operations, and 3) environmental.

Process advantages with Calderon cokemaking over conventional by-product cokemaking include:

- First, higher productivity and quality. The reactor tube is charged with coal that has been consolidated to bulk densities over $60 \mathrm{lb} / \mathrm{ft}^{3}$ and can be carbonized and pushed. Traditionally, increasing the bulk density of a given coal blend improves productivity and coke quality parameters but, unfortunately, also increases the coking pressure and its associated problems in slot-type ovens.

- Second, higher yield. In the sealed reactor tube, carbonization can be conducted at high pressures, typically 15 psig or higher. Carbonization at higher pressure 
reduces by-product yield and increases coke yield. By-product carbonization techniques require near ambient carbonization pressures to minimize leakage of coke oven gases through doors, lids, and offtakes into the atmosphere.

- Third, reactor tube strength. The inherent strength of the reactor tube results in less restrictive coking pressure limitations, in fact, a coal blend which contained $50 \%$ low volatile coal was carbonized with no resultant pushing problems or damage to the reactor tube. Use of additional quantities of low volatile coal will improve yield.

Because of these advantages, the commercial use of this process would allow an expanded range of usable coals as well as the use of higher-pressure, possibly lower cost, low volatile coals that can not be safely used in conventional by-product ovens. In addition, the reactor design and operation permits the continuous measurement and control of final coke temperature which will optimize coke strength and minimize the heat consumption requirements.

In terms of operations, the Calderon process is much simpler than a conventional coke battery, will require fewer operating personnel, and is amenable to complete computer automated control. There are no moving machinery-larry cars, door machines, pusher machines, or quench cars. In addition, because the Calderon system uses a modular design, maintenance on individual reactor tubes will not affect adjacent reactor tubes. This should result in easier maintenance and minimal production losses. Because of the simplicity of operation, the cost to operate a battery of Calderon reactor tubes is expected to be significantly less than that of a conventional by-product battery of equivalent capacity.

Environmentally, the Calderon process appears to have exceptional capabilities. There are no oven doors, charging hole lids, offtakes, or standpipe caps to leak to the atmosphere. The Calderon cokemaking process is totally enclosed and should have very low emission rates.

\section{Development Concerns}

The Calderon Cokemaking Process has significant advantages over existing coke making processes. However, certain areas need resolution before the process can be commercially acceptable. The refractory heating tiles for the reactor tube need to be fully installed and tested to determine life expectancy. On the feed end of the tube, a charging tube assembly needs to be designed to withstand the inherent problems associated with the fluid-like properties of dried or preheated coal, and the plunger seal has to be designed for continuous operation. On the coke discharge end of the tube, a reliable material handling system needs to be designed to control the discharge of hot coke into an enclosed quench system. And finally, with a higher capacity heating system, basic carbonization data need to be developed for this new process, i.e., coking rate vs. coke size and quality parameters for a much wider range of coal types than was tested during the pilot scale tests.

\section{Future Work}

Scale up of the Calderon Cokemaking Process is the next step. A full size reactor tube is needed to determine commercial scale feasibility. This includes evaluation of 1) production rates, coke quality, and environmental effects, 2) operation at faster coking rates, 3) the operation and maintenance requirements of the refractory heating tiles, and 4) capital and operating costs. 
The design of the full size reactor tube is underway. This initial reactor will be rated at 200 tons per day and after one-year of operation will produce enough coke for a full-scale blast furnace trial. 


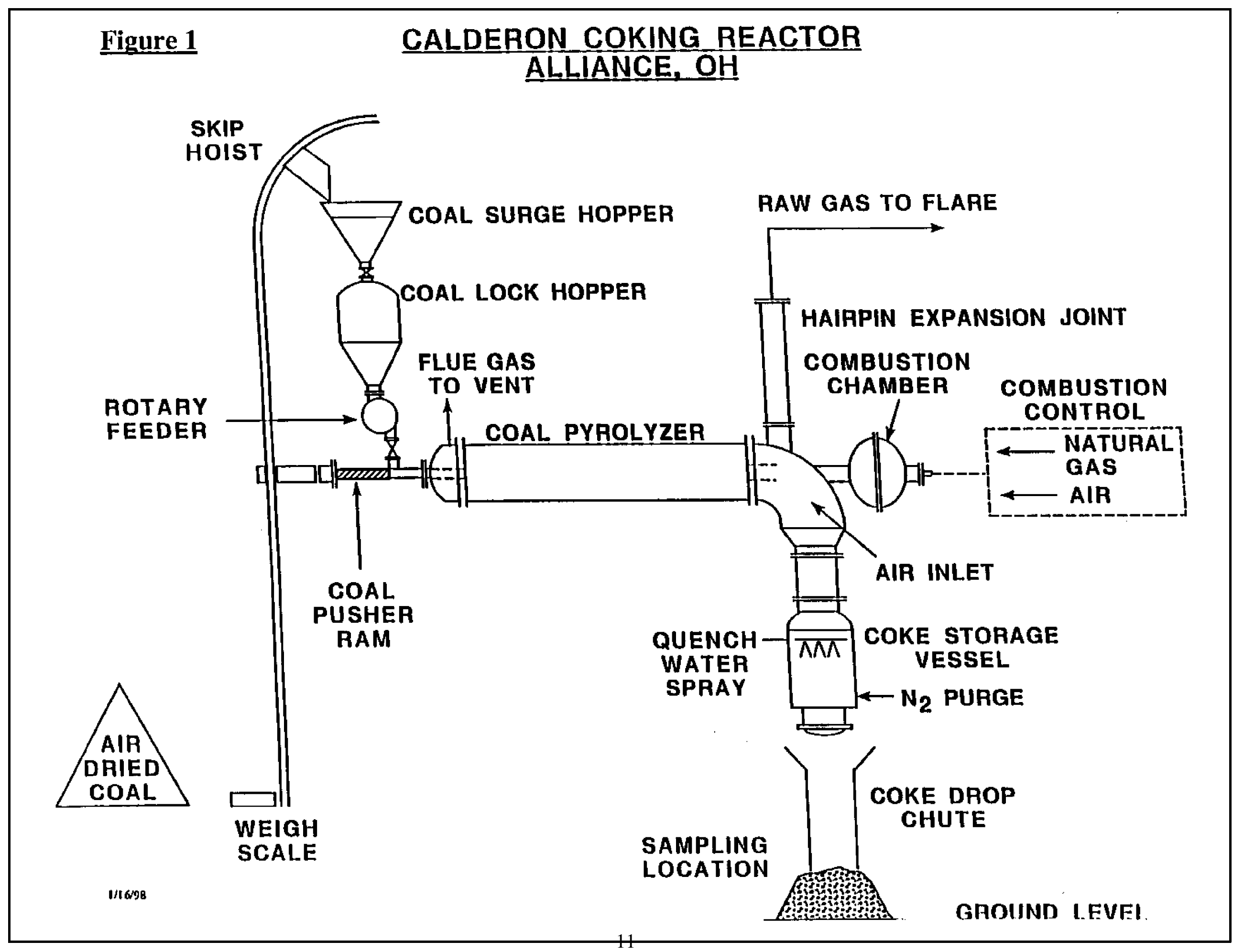




\section{Conclusion}

The past quarter was very fruitful by virtue of Bethlehem Steel's cash commitment for the project and by the recognition of the International Iron \& Steel Institute of the merit of the Calderon cokemaking technology, by requesting a presentation of the technology to top executives of this worldwide and prestigious organization.

The activities of the next quarter will focus on the following:

- Consolidation of the team players; namely, Bethlehem Steel, Bechtel, Calderon and possibly U.S. Steel.

- The start of detail engineering for the full size demonstration.

- U.S. Government contribution of its share for the project.

Submitted by:
Albert Calderon
Project Director 